Macedonian Pharmaceutical Bulletin, 66 (Suppl 1) 225 - 226 (2020)

Online ISSN $1857-8969$

UDC: 615.454.2.032.671:618.15-022.7

DOI: 10.33320/maced.pharm.bull.2020.66.03.112

Short communication

\title{
The influence of surfactants on the content of clindamycin phosphate in macrogol based compounded vagitories
}

\author{
Vesna Savić ${ }^{*}$, Slavica Sunarić ${ }^{1}$, Jelena $\check{Z}$ ivković $^{1}$, Milica Martinović ${ }^{1}$, Ivana Nešić ${ }^{1}$ \\ Ivana Gajić ${ }^{2}$ \\ ${ }^{1}$ Faculty of Medicine, Blvd. Dr Zorana Djindjica 81, 18108 Nis, Republic of Serbia \\ ${ }^{2}$ Faculty of Technology, Blvd. Oslobođenja 124, 16000 Leskovac, Republic of Serbia
}

\section{Introduction}

Vaginal route is often used for administration of different type of drugs (Đurić, 2004). Ideal vaginal preparation should be easy and painless to use, economical, widely available and safe for long-term use (Neves and Bahia, 2006). Vagitories are spherical or conical dosage forms intended for vaginal application. They consist of active substance dissolved or uniformly dispersed in a suitable, nonirritating base (Ph. Jug. V). Depending on whether vagitory bases are oleaginous or hydrophilic, they melt at body temperature or dissolve in body fluids (Krajšnik et al., 2013). Surfactants are added to enable emulsification of liquid components and better wetting of dispersed particles which can lead to improving of the release process and increasing of the spread capacity per application (Đurić, 2004). Clindamycin is a bacteriostatic lincosamide active against G-positive aerobes and a wide range of anaerobes, and is often used in treatment of bacterial vaginosis. (Sweetman, 2009).

The aim of this study was to make macrogol based vagitories, with $120 \mathrm{mg}$ of clindamycin phosphate incorporated in each of vagitory, with or without nonionic surfactant (Tween 80), using compounding method and to determine the content of the active substance (clindamycin phosphate) in the prepared vagitories.

\section{Materials and methods}

Formulation and preparation of vagitories

Six macrogol-based clindamycin phosphate vagitories were made when $8.21 \mathrm{~g}$ of liquid Macrogol 400 (Defond Chemical, China) and $5.48 \mathrm{~g}$ of solid Macrogol 6000 (Defond Chemical, China), were melted in patena using laboratory water bath. Melted base was then gradually added to patena with $0.72 \mathrm{~g}$ clindamycin phosphate (Sigma Aldrich, Darmstadt, Germany), homogenously stirred and later poured into metal molds, lubricated with liquid paraffin (Avena Lab - Farmadria, Vršac, Serbia). After releasing vagitories from the molds, each vagitory was measured. Vagitories with Tween 80 (Avena Lab - Farmadria, Vršac, Serbia) were made the same way, except that in addition to $7.78 \mathrm{~g}$ of macrogol 400 and $5.18 \mathrm{~g}$ of macrogol 6000, also $0.72 \mathrm{~g}$ of Tween 80 was melted.

Method of determining the content of clindamycin phosphate in pessaries

High performance liquid chromatography (HPLC) on chromatography system Agilent 1200 Series Diode Array and Multiple Wavelength detector (Agilent Technologies, USA) was used for determining the content of clindamycin phosphate in vagitories. ZORBAX Eclipse Plus C8 column (3,0 x $150 \mathrm{~mm} ; 3.5 \mu \mathrm{m}$ particle size) (Agilent) was used (temperature $40 \quad{ }^{\circ} \mathrm{C}$ ). Mobile phase (flow: 0.8 $\mathrm{mL} / \mathrm{min}$ ) consisted of acetonitrile:phosphate buffer $=$

*vsavic203@yahoo.com 
20:80 ( $\mathrm{pH}=2.5)$. Injected volume of samples was 10 $\mu \mathrm{L}$. Detection wavelength was $210 \mathrm{~nm}$ (Stanković et al., 2013). Tested samples were made by dissolving the entire vagitory in $50 \mathrm{~mL}$ of phosphate buffer. Afterwards, $0.83 \mathrm{~mL}$ of that solution (corresponding to the content of $2 \mathrm{mg}$ clindamycin phosphate) was taken using an automatic pipette and transferred to a normal $25 \mathrm{~mL}$ vessel supplemented with phosphate buffer $(\mathrm{pH}=2.5)$. Obtained concentration of samples was $80 \mu \mathrm{g} / \mathrm{mL}$. Basic standard solution of clindamycin phosphate was made by dissolving of $10 \mathrm{mg}$ of the substance in a normal $10 \mathrm{~mL}$ vessel in phosphate buffer $(\mathrm{pH}=2.5)$. The concentration of such solution was $1000 \mu \mathrm{g} / \mathrm{mL}$. The working standards of clindamycin phosphate used to record the chromatogram and obtain the reference standard curve were made by diluting of the basic standard solution with phosphate buffer $(\mathrm{pH}=2.5)$. In this way, 5 standard solutions of the following concentrations were made: $40 \mu \mathrm{g} / \mathrm{mL}, 60 \mu \mathrm{g} / \mathrm{mL}, 80$ $\mu \mathrm{g} / \mathrm{mL}, 100 \mu \mathrm{g} / \mathrm{mL}$ and $120 \mu \mathrm{g} / \mathrm{mL}$.

\section{Results and discussion}

After compounding of vagitories, each vagitory was removed from the mold and measured. Average mass of macrogol-based clindamycin phosphate vagitories was $2.39 \mathrm{~g}$ while average mass of the ones with Tween 80 was $2.38 \mathrm{~g}$, so mass variations were within limits prescribed by $\mathrm{Ph}$ Jug V (5\% from expected value $-2.4 \mathrm{~g}$ )

For calculating the content of clindamycin phosphate in vagitories, equation of calibration curve was used $\left(\mathrm{y}=2.3691 \mathrm{x}+4.392, \mathrm{R}^{2}=0.9999\right)$.

In order to determine influence of base on active substance content, the chromatograms of placebo, standard and samples were recorded. A placebo was made solely of excipient (macrogols) The method proved to be selective because no peaks appeared on the placebo chromatograms with the retention time of clindamycin phosphate (3.534 $\mathrm{min})$.

The method also proved to be accurate since chromatograms of standard samples with wellknown clindamycin phosphate concentration in macrogol basis (120 mg per vagitory) showed peak at a retention time of $3.213 \mathrm{~min}$. Concentrations of clindamycin phosphate (mg/pessary) and recovery values were calculated. The recovery value (the ratio of the clindamycin phosphate concentration found in the sample and the expected clindamycin phosphate concentration) was $102.9 \%$.

Six chromatograms each of macrogol based clindamycin phosphate vagitory samples with or without Tween 80 were recorded. The mean peak area was calculated and then the equation of calibration curve of clindamycin phosphate standard solutions was used to calculate the mean concentration of clindamycin phosphate in the macrogol pessaries. The obtained clindamycin phosphate concentration in macrogol based vagitories without Tween 80 was $115.9 \pm 8.2$ (recovery value 96.6\%), while the mean concentration in the pesaries with Tween 80 was 119.2 \pm 2.3 (recovery value $99.3 \%$ ).

\section{Conclusion}

The results showed that the content of clindamycin phosphate was higher in macrogol vagitories with Tween 80 . Nonionic surfactants help releasing of active substance from the pharmaceutical form, therefore it can be assumed that it can be one of the reasons why the content of the active substance in vagitories with Tween 80 was higher. Next research may be related to the biopharmaceutical aspect of the influence of the bases in compounding. It is recommended to consider possibility of the validation of technological manufacturing process during compounding, depending on the applied excipients and additives.

\section{Acknowledgements}

Republic of Serbia - Ministry of Education, Science and Technological Development, Program for financing scientific research work, number 45103-68/2020-14/200133.

\section{References}

Jugoslovenska Farmakopeja (Ph. Jug. V), 2000. Savremeni zavod za zaštitu i unapređenje zdravlja. Savremena administracija, Beograd.

Krajšnik, D., Grbić, S., Đuriš, J., Đekić, L.J., Vasiljević, D., Kovačević, A., Čalija, B., 2013. Farmaceutska tehnologija II - Praktikum. Farmaceutski fakultet, Beograd.

Neves das, J., Bahia M.F., 2006. Gels as vaginal drug delivery systems. Int. J. Pharm. 318, 1-14.

Stanković, M., Savić, V., Marinković, V., 2013. Determination of clindamycin phosphate in different vaginal gel formulations by reverse phase high performance liquid chromatography. Acta Fac. Med. Naiss. 30(2), 63-71.

Sweetman C.S., 2009. Martindale: The complete drug reference, thirty-sixth ed. The Pharmaceutical Press, London.

Đurić, Z., 2004. Farmaceutska biotehnologija sa biofarmacijom I deo. Nijansa, Zemun.

Maced. Pharm. Bull. 66 (Suppl 1) 225 - 226 (2020) 